Alaska Division of Geological \& Geophysical Surveys

MISCELLANEOUS PUBLICATION 154

\title{
COLOR-INDEXED ELEVATION MAPS FOR FLOOD-VULNERABLE COASTAL COMMUNITIES IN WESTERN ALASKA
}

by

Timothy Tschetter, Nicole Kinsman, and Aimee Fish

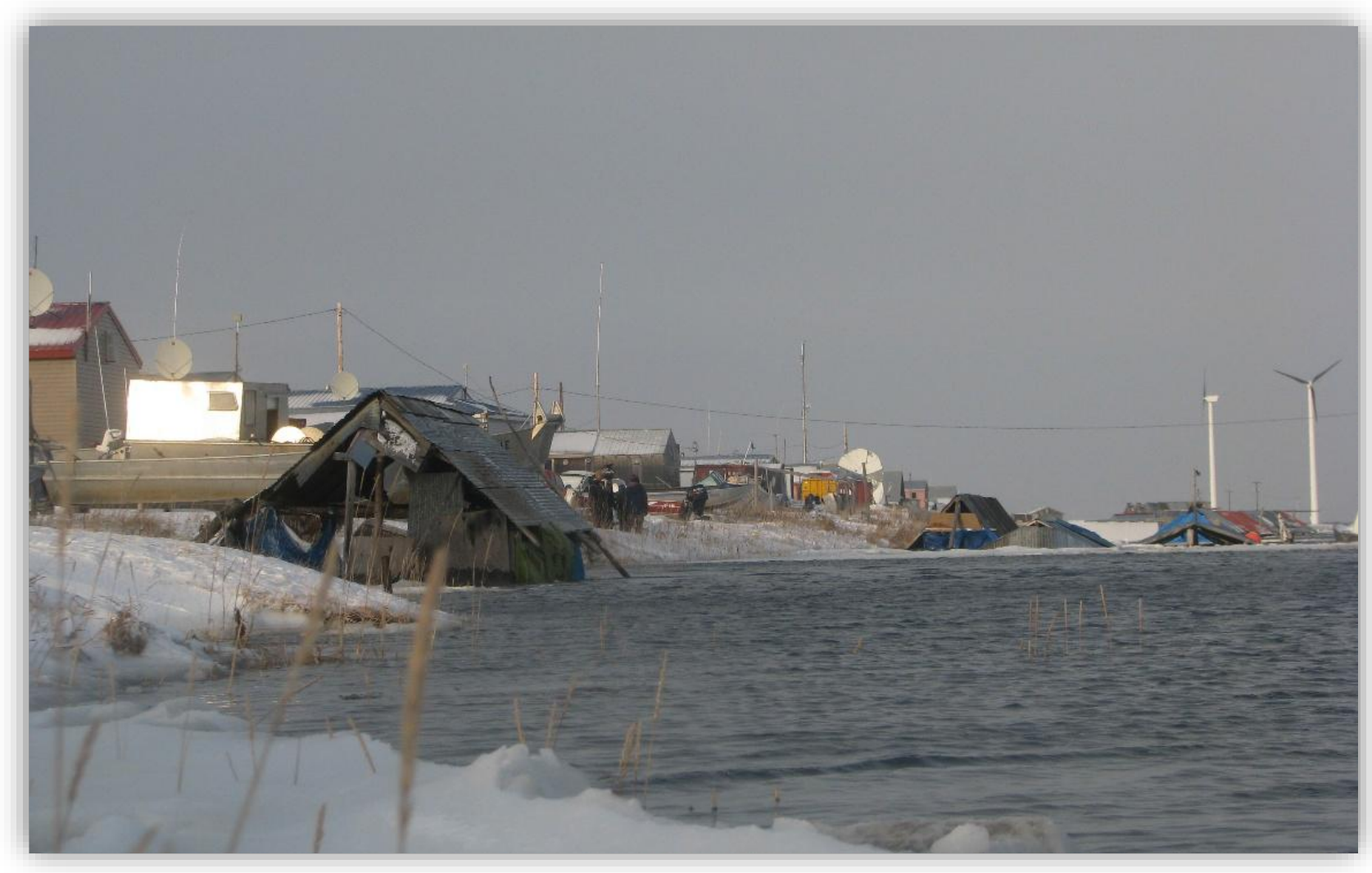

Coastal flooding along the Tagoomenik River in Shaktoolik, Alaska, in November 2011 (photograph by Elmer Bekoalok).

October 2014

Released by

STATE OF ALASKA

DEPARTMENT OF NATURAL RESOURCES

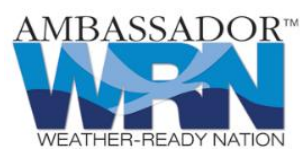

Division of Geological \& Geophysical Surveys 3354 College Rd.

Fairbanks, Alaska 99709-3707
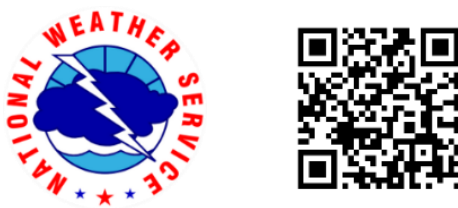



\section{Overview}

This map series is a joint effort by the Alaska Division of Geological \& Geophysical Surveys (DGGS) and the National Weather Service (NWS) to merge best-available datasets into a tool that can streamline communication about forecasted water levels, local elevations, and potentially impacted infrastructure during storm events that may cause coastal flooding (fig. 1). These maps are not designed to function as flood inundation maps, but to serve as a temporary tool to communicate about elevations in at-risk coastal communities until true inundation mapping can be completed. Pilot work to test the usefulness of this map format is presented for five communities: Kivalina, Shishmaref, Golovin, Shaktoolik, and Unalakleet.

\section{Community}

Maps
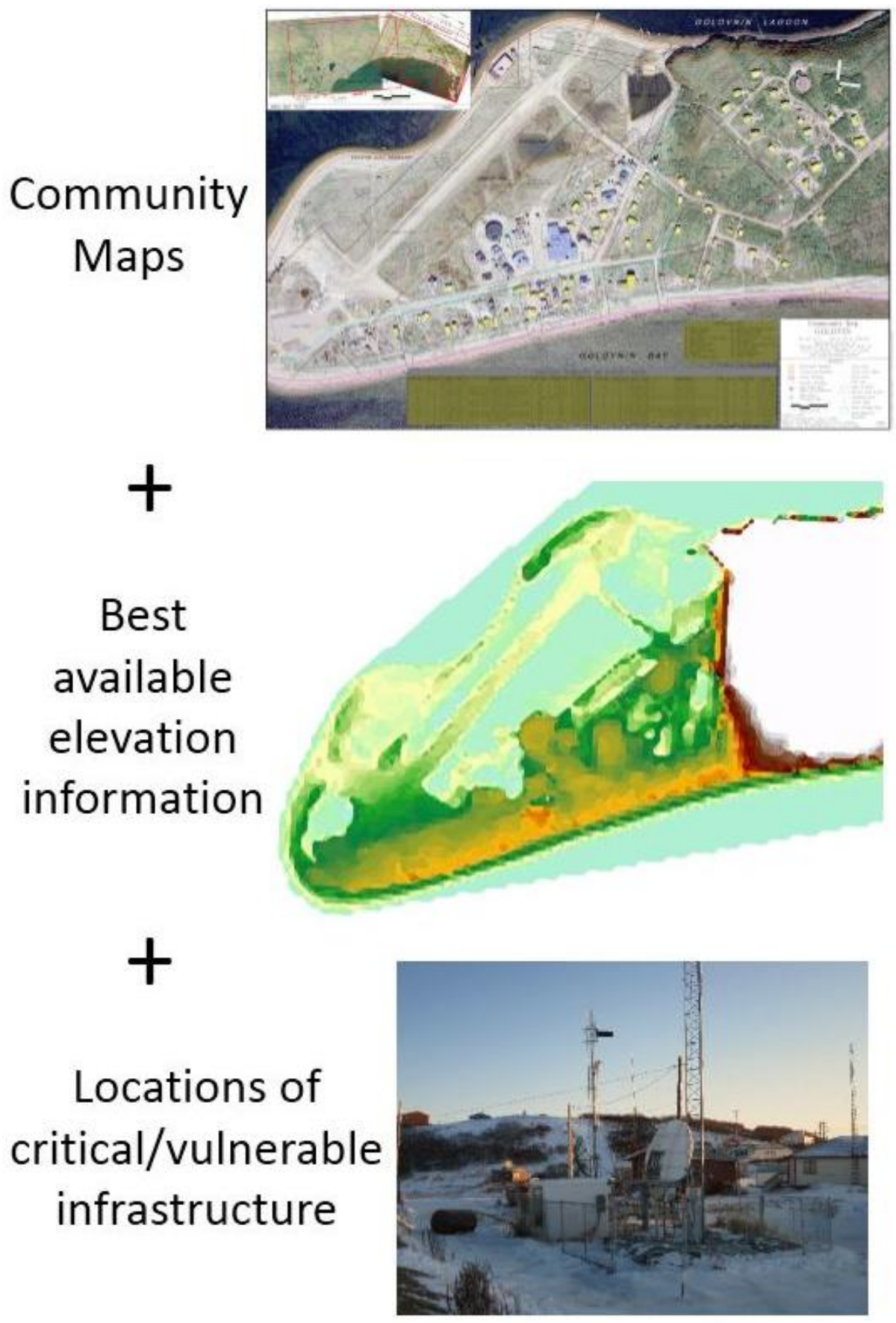

Figure 1. Graphical summary of the compilation of best available data sets to produce community-specific, color-indexed elevation maps. 


\section{Purpose/Need}

When an extreme storm event is forecast, it is imperative for local community leaders and emergency managers to quickly and effectively communicate with the NWS regarding:

- How high floodwater may reach

- From what direction(s) flooding may be most severe

- Where impacts are most likely to occur

- Which critical infrastructure is potentially at risk

- How this event will differ from past storms at a local level

Unfortunately, there are challenges that can impede this dialog. An emergency manager in Anchorage may not be familiar with the location of a village's power supply; a community leader may not know the elevation of the evacuation road; a forecaster may use unfamiliar language that is confusing in an emergency context. For some simplified definitions of some common terms, please see Appendix 1.

During the 2011 and 2013 fall storm seasons, Alaska NWS staff struggled to convey relevant coastal storm impacts to communities along the west coast of Alaska. Forecast water levels were expressed in units above local tide or above Mean Lower Low Water (MLLW); this did not effectively convey the threat to local decision makers. Staff with the State of Alaska Emergency Operations Center challenged the NWS to use language that community members could understand, suggesting forecasters describe potential impacts to critical infrastructure as a more effective approach.

At this time, the full suite of data necessary for coastal flood inundation mapping is not yet available in many parts of Alaska. To meet the identified need for an interim tool, a widely-used map series that is color-indexed by elevation and linked to a table of relevant reference frames (surveyed elevations and tidal datums such as MLLW) may facilitate real-time discussions during storm events. In combination with community dialog, this work will contribute toward enhancing an 'Impacts Catalog' to assist the NWS in their decisions to issue warnings and further the goals of NOAA's Weather-Ready Nation initiative.

\section{What are the differences between a Flood Inundation Map and a Color-Indexed Elevation Map?}

The color-indexed elevation maps in this series are not a substitute for flood inundation maps; the colored areas on these maps do not directly correspond to flood warning zones, but to pure elevations. When a storm surge impacts a community, local currents, wind, and waves will lead to different peak water levels in different areas. For example:

- A low area in the middle of town may not flood if it is surrounded by higher elevation

- Elevated ocean water levels may prevent drainage from a nearby river, leading to overflow flooding along the riverbanks

- Large waves may break and run high up on one portion of a beach, while farther down the same beach a protective sandbar causes the waves to break offshore

Unlike color-indexed elevation maps, flood inundation maps will account for these variables in local conditions by incorporating advanced models of where water will flow in a range of scenarios. Flood zones are established based on the likelihood that an event will occur in any given year (a 2-year flood zone has a 50/50 chance of flooding each year, like flipping a coin). The creation of flood inundation maps is a lengthy process that requires a detailed record of local conditions-data not yet available in many of Alaska's small communities. 


\section{Approach and Community Selection}

To evaluate this new type of tool, DGGS worked with NWS to select five communities to include in this pilot project (fig. 2). The selection process was based on need (documented flood events), the possession of an established Local Hazard Mitigation Plan, and the availability of existing data required to compile these maps in a timely fashion. Minimal data needs include:

1. Imagery and Linework

Alaska Division of Community and Regional Affairs Community Profile Maps (DCRA, 2014)

2. Detailed Surface Elevations

Most recent lidar or photogrammetrically-derived digital elevation model

3. A conversion factor between local water levels and elevations on land NOAA tidal datum with a tidal benchmark of known elevation (NGS-published height)

4. Storm Surge Guidance

NWS guidance location points with both storm surge and tidal prediction capabilities

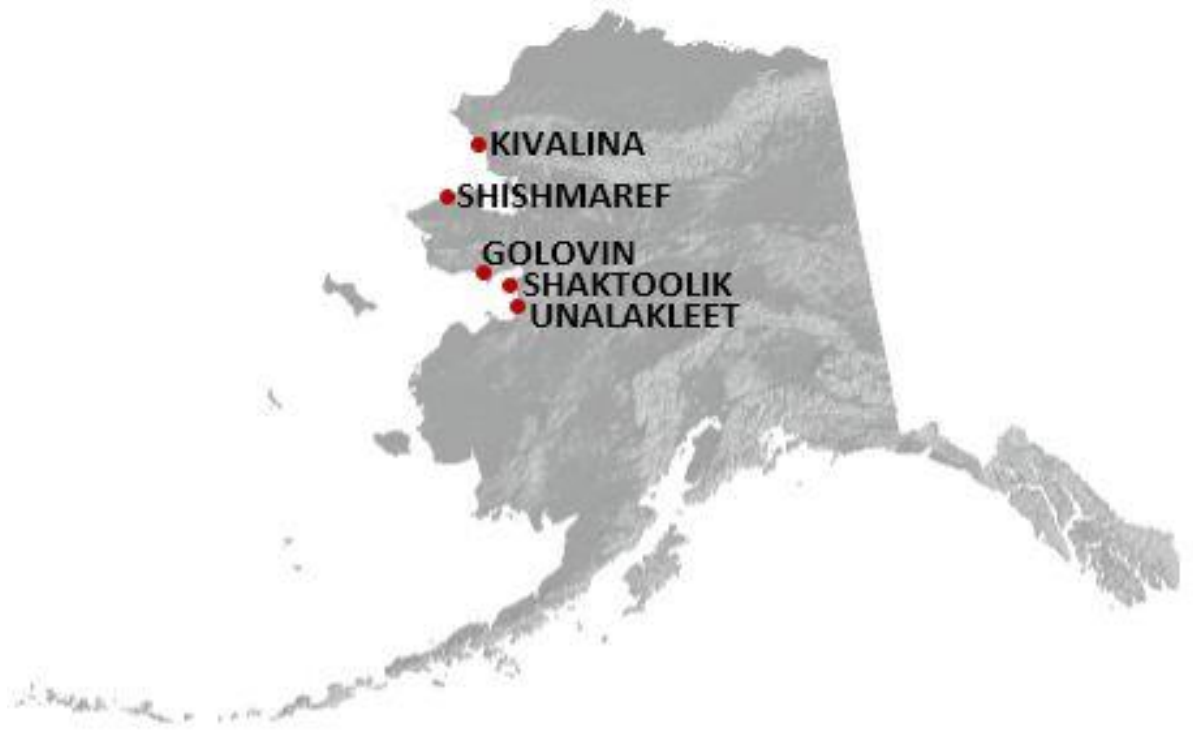

Figure 2. Location map of the five communities included in the pilot project.

The production of color-indexed elevation maps and associated conversion tables varied based on the quality and format of the data listed above. Details about this process, including the specific source data and production steps, are provided for each community in Appendix 2 and summarized in table 1 . A community feedback meeting was held on September 9, 2013, to identify critical infrastructure and ensure a useful format for the final publication.

\section{Intended Use}

The maps in this series are intended to facilitate two-way communication about situational storm surge impacts. Each map has highlighted elevation intervals in developed, low-lying areas; maps also highlight any critical infrastructure. The map sheets are all maintained separately to allow for re-versioning as vertical datums are refined in western Alaska. 
Table 1. Summary of data sets used in the preparation of each color-indexed map.

\begin{tabular}{|l|l|l|l|l|l|}
\hline \multicolumn{1}{|c|}{ Community } & \multicolumn{1}{|c|}{ Shishmaref } & \multicolumn{1}{c|}{ Kivalina } & \multicolumn{1}{c|}{ Unalakleet } & \multicolumn{1}{c|}{ Shaktoolik } & \multicolumn{1}{c|}{ Golovin } \\
\hline DCRA Map & 2004 & 1999 & 2004 & 2004 & 2004 \\
\hline Imagery & 2004 (DCRA) & 2013 (DCRA) & 2014 & 2014 & 2004 \\
\hline Elevation Model & 2004 lidar & 2004 lidar & 2014 model & 2014 model & 2013 lidar \\
\hline Tidal Predictions & Yes & Yes & Yes & Yes & No \\
\hline Tidal Datum & Est. 2003 & Est. 1985-86 & Est. 2011 & Est. 2010 & Approx. 2012 \\
\hline Surge Guidance & Yes & Limited & Yes & Yes & Yes \\
\hline $\begin{array}{l}\text { Local Hazard } \\
\text { Mitigation Plan }\end{array}$ & 2010 & 2007 & 2008 & 2009 & 2008 \\
\hline $\begin{array}{l}\text { Existing flood map } \\
\text { tools }\end{array}$ & $\begin{array}{l}\text { FEMA Flood } \\
\text { Insurance Study } \\
\text { (2009) }\end{array}$ & No & $\begin{array}{l}\text { NRCS Floodplain } \\
\text { Management Map } \\
\text { (2003) }\end{array}$ & $\begin{array}{l}\text { USACE Coastal } \\
\text { Flooding Analysis } \\
\text { Maps (2011a) }\end{array}$ & No \\
\hline
\end{tabular}

Elevations can be defined relative to various reference frames, which can cause confusion when information is transmitted between different users. By supplying a conversion table with each map, users from different backgrounds can determine which colors correspond to the reference frame they are most comfortable with and communication can occur with a simplified color-based scheme (for example, see fig. 3). Each conversion table is accompanied by a graphic of significant infrastructure elevations as well as documented and modeled water levels in each community (compiled from U.S. Army Corps of Engineers [USACE], 2011b; Chapman and others, 2009; Kinsman and DeRaps, 2012). Combining this information with knowledge of local flood patterns, storm track, and considerations such as the absence or presence of ice in the nearshore, local planners can use these calculations to make immediate decisions for storm-response needs. NWS forecasters can also speak directly to local planners about at-risk infrastructure with a shared reference frame and visual aid by using these maps as a discussion platform.

Please note the following disclosures/use limitations:

- These maps illustrate elevations and are not intended for use in the definition of flood zones. Flood levels are not perfectly flat and will not directly correspond to specific elevations.

- Vertical and horizontal accuracies vary by location.

- Best available data sets in Alaska are not always up-to-date. Temporal changes, human or naturally induced, could have occurred that would cause the elevations depicted on these map figures to no longer represent actual surface conditions.

Examples: $\diamond$ Houses or infrastructure may have moved since DCRA linework was completed

$\diamond$ Local engineering projects might raise a road or add a seawall

$\diamond$ Beaches and sand spit change shape regularly

- Colors are restricted to areas of known elevation; in some cases the best available elevation model does not cover the entire DCRA Community Map area. 


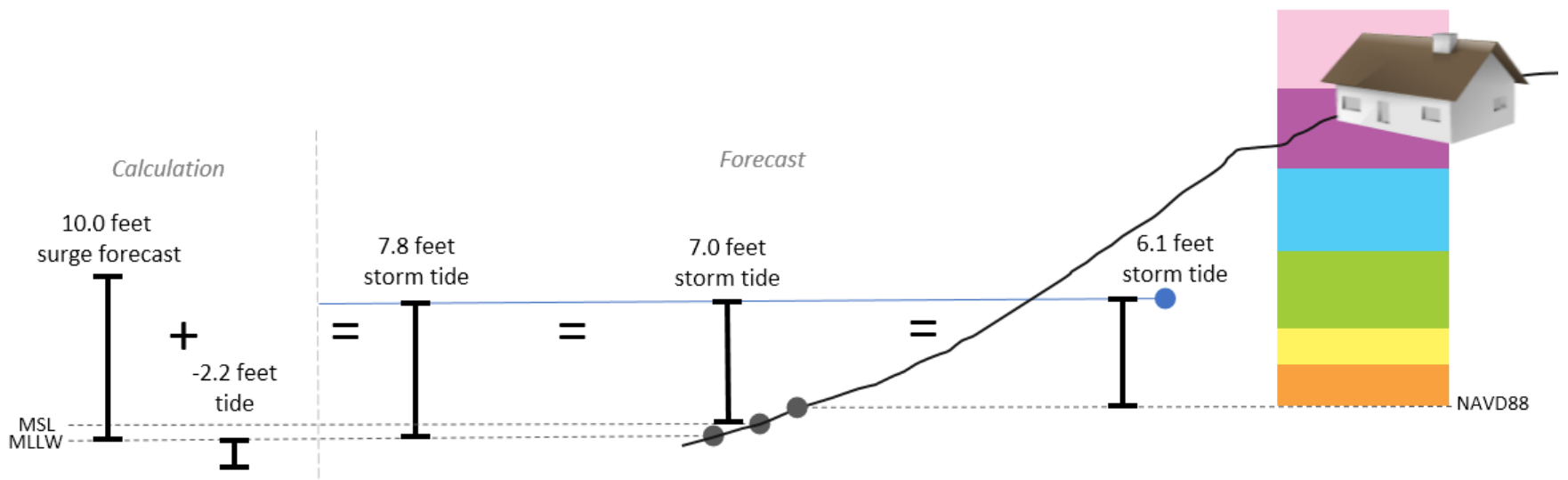

Figure 3. A storm tide level is the sum of the surge forecast and the local tide prediction. For example, a storm surge forecast (10.0 feet MLLW) may be added to the local tide prediction at the projected time of landfall (2.2 feet below MLLW) to calculate the storm tide at peak surge (7.8 feet above MLLW). This same storm tide value may be reported in many ways: 7.8 feet above MLLW, 7.0 feet above MSL or 6.1 feet above NAVD88. With the table in this report, these calculations (or additional setup/wave runup factors) can be simplified to "water levels that correspond to local elevations highlighted in green."

\section{Recommendations}

This pilot work will be available in time for the peak of the 2014 coastal storm season. If used, feedback from local leaders and NWS staff will determine if this work is appropriate to extend to additional communities in Alaska. If this approach is continued, maps may be updated as existing datasets are improved and new products become available.

An additional use for these maps is to share knowledge about what colors corresponded to the peak water levels in different parts of a community if a flood event does occur. This could provide valuable information to NWS to improve local impact catalogs and verify coastal flood forecasts and warnings.

Ultimately, flood inundation maps can be developed that will replace these stopgap elevation tools. To promote the eventual development of flood inundation products throughout Alaska, an emphasis must be placed on collecting high-resolution ( $<1 \mathrm{~m}$ ground spacing) elevation and bathymetry measurements in the coastal zone (vertical accuracies of $<25 \mathrm{~cm}$ are recommended), enhancing tidal predictions and tidal datums, and improving storm surge models with descriptive storm surge recurrence intervals.

\section{Additional Resources}

Up-to-date storm surge information may be obtained from NWS advisories, warnings, and situational awareness bulletins (http://www.arh.noaa.gov/). For more technical users, storm surge and storm tide guidance is available for selected parts of Alaska from the NWS Meteorological Development Laboratory's Extra-tropical Water Level website (http://www.nws.noaa.gov/mdl/etsurge/).

We strongly encourage residents in small coastal communities to adopt and update a FEMA-approved Local Hazard Mitigation Plan and to review the Alaska Division of Homeland Security \& Emergency Management (DHS\&EM)'s 2013 Alaska Emergency Response Guide for Small Communities, which includes checklists, recommendations, and resources for local emergency managers. An additional way to prepare your community for future storm events is to adopt a Small Community Emergency Response Plan (SCERP). For additional information or to obtain a SCERP toolkit, please contact the Alaska DHS\&EM. 


\section{Acknowledgments}

This publication has been prepared on an expedited timeline so that it may be an available resource in the 2014 fall storm season. Development and production of the color-indexed maps was completed by Timothy Tschetter (DGGS/UAF). Accompanying text and figures were prepared by Nicole Kinsman (DGGS), Timothy Tschetter, and Aimee Fish (NWS).

Funding to complete this project has been generously provided by the National Oceanic and Atmospheric Administration in conjunction with the Alaska Ocean Observing System. This work was also funded, in part, with qualified outer continental shelf oil and gas revenues through the Coastal Impact Assistance Program, U.S. Fish and Wildlife Service, U.S. Department of the Interior. The views and conclusions contained in this document are those of the authors and should not be interpreted as representing the opinions or policies of the U.S.

Government. Mention of trade names or commercial products does not constitute their endorsement by the U.S. Government.

The authors extend their gratitude to participants in the community outreach meeting on September 9, 2014: Steve Ivanoff (Unalakleet); Zena Barr, Howard Weyiouanna, and Willard P. Jones (Shishmaref); Toby Anungazuk, Jr., Carol Oliver, and Jack Fagerstrom (Golovin); Isabelle Jackson, Edgar Jackson, and Edna Savetilik (Shaktoolik); and Millie Hawley (Kivalina). We also appreciated input from the NWS Fairbanks Weather Forecast Office. Matt Nolan (Fairbanks Fodar) expedited data collection, processing, and delivery for updated DEM and imagery needs over Unalakleet and Shaktoolik. John Lingaas (NWS) and David Williams (U.S. Army Corps of Engineers) generously provided their time to review this publication and their comments have greatly improved the final content. 


\section{Appendix 1. Useful Definitions}

\section{Types of Water Levels}

Many factors, including tides, atmospheric pressure, waves, and wind combine during an extreme storm to elevate water levels at the coast. Forecasters and scientists have specific names to describe each component that elevates the water level, and some components are more difficult to calculate than others. When all of these components are added together, the result is a prediction of the total water level at a particular location.

\begin{tabular}{|c|c|c|c|c|c|}
\hline \multicolumn{3}{|c|}{$\begin{array}{l}\text { COASTAL STORM WATER LEVEL } \\
\text { COMPONENTS }\end{array}$} & Full Definition & \begin{tabular}{|l} 
How \\
Determined
\end{tabular} & Easy Explanation \\
\hline \multicolumn{3}{|l|}{ Mean Sea Level } & $\begin{array}{l}\text { The average height of all } \\
\text { water levels in a local } \\
\text { area under normal } \\
\text { conditions }\end{array}$ & Tide gauge & $\begin{array}{l}\text { This is where the water } \\
\text { level is usually located }\end{array}$ \\
\hline Tide Level & $\begin{array}{l}\text { Storm } \\
\text { Tide } \\
\text { Level }\end{array}$ & $\begin{array}{l}\text { Total } \\
\text { Water } \\
\text { Level }\end{array}$ & $\begin{array}{l}\text { Regular variation in the } \\
\text { water level caused by } \\
\text { sun/moon gravitational } \\
\text { forces and the earth's } \\
\text { rotation }\end{array}$ & $\begin{array}{l}\text { Tidal } \\
\text { predictions } \\
\text { modeled by } \\
\text { NOAA }\end{array}$ & $\begin{array}{l}\text { This includes both high and } \\
\text { low tide levels under normal } \\
\text { weather conditions }\end{array}$ \\
\hline Storm Surge & & & $\begin{array}{l}\text { Elevated ocean levels } \\
\text { that arise from a } \\
\text { combination of onshore- } \\
\text { directed wind stresses } \\
\text { and reduced atmospheric } \\
\text { pressure }\end{array}$ & $\begin{array}{l}\text { Forecasted by } \\
\text { regional NWS } \\
\text { ocean models }\end{array}$ & $\begin{array}{l}\text { This is the overall rise in the } \\
\text { open ocean water level due } \\
\text { to storm conditions }\end{array}$ \\
\hline \multicolumn{3}{|l|}{ Nearshore Setup } & $\begin{array}{l}\text { An increase in water level } \\
\text { due to waves and the } \\
\text { shoreward transport of } \\
\text { water }\end{array}$ & $\begin{array}{l}\text { Calculated or } \\
\text { modeled } \\
\text { based on local } \\
\text { conditions and } \\
\text { typical storm } \\
\text { characteristics }\end{array}$ & $\begin{array}{l}\text { An additional rise in the } \\
\text { water level along open } \\
\text { coastlines during a storm as } \\
\text { waves 'pile up' against the } \\
\text { shore }\end{array}$ \\
\hline Wave Runup & & & $\begin{array}{l}\text { The maximum height } \\
\text { breaking waves can reach } \\
\text { on a shoreface }\end{array}$ & $\begin{array}{l}\text { Calculated or } \\
\text { modeled } \\
\text { based on local } \\
\text { conditions and } \\
\text { typical storm } \\
\text { characteristics }\end{array}$ & $\begin{array}{l}\text { Breaking waves have extra } \\
\text { energy that can cause the } \\
\text { water to rush up even } \\
\text { higher in some locations. } \\
\text { This is an elevation where } \\
\text { your feet may be splashed } \\
\text { but you are not standing in } \\
\text { water. }\end{array}$ \\
\hline
\end{tabular}




\section{Vertical Reference Frames (Datums)}

Vertical reference frames that are included on the conversion table have been selected based on their applicability to emergency response needs in the coastal zone. These datums, their primary uses, and definitions are summarized below.

Mean Lower Low Water (MLLW) - in feet

Commonly used: $\quad$ by NWS forecasters

- on NOAA nautical charts (depths)

- to define the landward edge of United States waters

Simple definition: The average height of the lowest water levels in a local area

Formal Definition: Average of the lower low water height of each tidal day observed at a tide station over a 19-Year National Tidal Datum Epoch or a Modified 5-Year Epoch. For stations with shorter series (1-3 months is common in Alaska), comparison of simultaneous observations with a control tide station is made in order to derive the equivalent Modified or National Tidal Datum Epoch.

Mean Sea Level (MSL) - in feet and meters

Commonly used: $\quad$ to report NOAA tide predictions

- by coastal scientists and modelers

Simple definition: The average height of all water levels in a local area

Formal Definition: The arithmetic mean of hourly heights observed over a 19-Year National Tidal Datum Epoch or a Modified 5-Year Epoch. Shorter series (1-3 months is common in Alaska) are specified in the name; for example, monthly mean sea level and yearly mean sea level.

\section{North American Vertical Datum of 1988 (NAVD88) - in feet and meters}

Commonly used: $\quad$ on topographic maps

- by land surveyors and engineers

Simple definition: The standard for land elevations in the United States

Formal Definition: A standardized geodetic datum based on orthometric height (a height above the geoid or equipotential gravitational reference surface that approximates an idealized global sea surface). Orthometric heights may be determined by combining a measured height above the ellipsoid surface with a model of the geoid. NAVD88 elevations are obtained in this manner by combining the vertical component of the NAD83 ellipsoid, which can be measured using a GPS receiver or though differential leveling, with GEOID12A (the best available geoid model). 


\section{Appendix 2. Technical Documentation on Map Preparation}

\section{Table of Color-Indexed Map Products (Sheets)}

\begin{tabular}{|l|l|}
\hline Shishmaref & $\begin{array}{l}\text { Shishmaref Numerical Elevation Table 1 } \\
\text { Color-Indexed Shishmaref Community Map Sheet } 1 \\
\text { Color-Indexed Shishmaref Community Map Sheet } 2 \\
\text { Color-Indexed Shishmaref Area Use Map Sheet 3 }\end{array}$ \\
\hline Kivalina & $\begin{array}{l}\text { Kivalina Numerical Elevation Table 1 } \\
\text { Color-Indexed Kivalina Community Map Sheet } 1 \\
\text { Color-Indexed Kivalina Area Use Map Sheet 2 }\end{array}$ \\
\hline Unalakleet & $\begin{array}{l}\text { Unalakleet Numerical Elevation Table 1 } \\
\text { Color-Indexed Unalakleet Community Map Sheet 1 } \\
\text { Color-Indexed Unalakleet Community Map Sheet } 2 \\
\text { Color-Indexed Unalakleet Community Map Sheet 3 } \\
\text { Color-Indexed Unalakleet Area Use Map Sheet 4 }\end{array}$ \\
\hline Shaktoolik & $\begin{array}{l}\text { Shaktoolik Numerical Elevation Table 1 } \\
\text { Color-Indexed Shaktoolik Community Map Sheet 1 } \\
\text { Color-Indexed Shaktoolik Community Map Sheet } 2 \\
\text { Color-Indexed Shaktoolik Area Use Map Sheet 3 }\end{array}$ \\
& $\begin{array}{l}\text { Golovin Numerical Elevation Table 1 } \\
\text { Color-Indexed Golovin Community Map Sheet 1 } \\
\text { Color-Indexed Golovin Community Map Sheet } 2 \\
\text { Color-Indexed Golovin Area Use Map Sheet 3 }\end{array}$ \\
\hline Golovin &
\end{tabular}

Table of Best Available Data

\begin{tabular}{|c|c|c|c|}
\hline Component & Format & Source & Date \\
\hline \multicolumn{4}{|c|}{ SHISHMAREF } \\
\hline Community and Area Maps (3) & Annotated aerial imagery & DCRA, 2014 & 2004 \\
\hline Digital Elevation Model & Interpolated lidar point-cloud & NOAA and others, 2004 & 2004 \\
\hline Tidal/Geodetic Datum Conversion & Measured offset & CO-OPS/NGS (NOAA, 2014) & 2003 \\
\hline \multicolumn{4}{|c|}{ KIVALINA } \\
\hline Community and Area Maps (2) & Annotated aerial imagery & DCRA, 2014 & 1999 \\
\hline Digital Elevation Model & Interpolated lidar point-cloud & NOAA and others, 2004 & 2004 \\
\hline Tidal/Geodetic Datum Conversion & Measured offset & CO-OPS/NGS (NOAA, 2014) & 1986 \\
\hline \multicolumn{4}{|c|}{ UNALAKLEET } \\
\hline Community and Area Maps (4) & Linework and annotations & DCRA, 2014 & 2004 \\
\hline Updated Imagery & Aerial imagery & DGGS (in production) & 2014 \\
\hline Digital Elevation Model & Digital photogrammetry & DGGS (in production) & 2014 \\
\hline Tidal/Geodetic Datum Conversion & Measured offset & CO-OPS/NGS (NOAA, 2014) & 2011 \\
\hline \multicolumn{4}{|c|}{ SHAKTOOLIK } \\
\hline Community and Area Maps (3) & Linework and annotations & DCRA, 2014 & 2004 \\
\hline Updated Imagery & Aerial imagery & DGGS (in production) & 2014 \\
\hline Digital Elevation Model & Digital photogrammetry & DGGS (in production) & 2014 \\
\hline Tidal/Geodetic Datum Conversion & Measured offset & CO-OPS/NGS (NOAA, 2014) & 2010 \\
\hline \multicolumn{4}{|c|}{ GOLOVIN } \\
\hline Community and Area Maps (3) & Annotated aerial imagery & DCRA, 2014 & 2004 \\
\hline Digital Elevation Model & Interpolated lidar point-cloud & DGGS (in production) & 2013 \\
\hline Tidal/Geodetic Datum Conversion & Estimated offset & DGGS (unpublished) & 2013 \\
\hline
\end{tabular}




\section{Vertical Datum Offset Calculations}

The local transformations between the geodetic and tidal datums presented below have been calculated using shared orthometric heights of a tidal benchmark in combination with local tidal station datum elevations from the 1983-2001 National Tidal Datum Epoch (fig. 4; NOAA, 2014; DGGS, 2014).

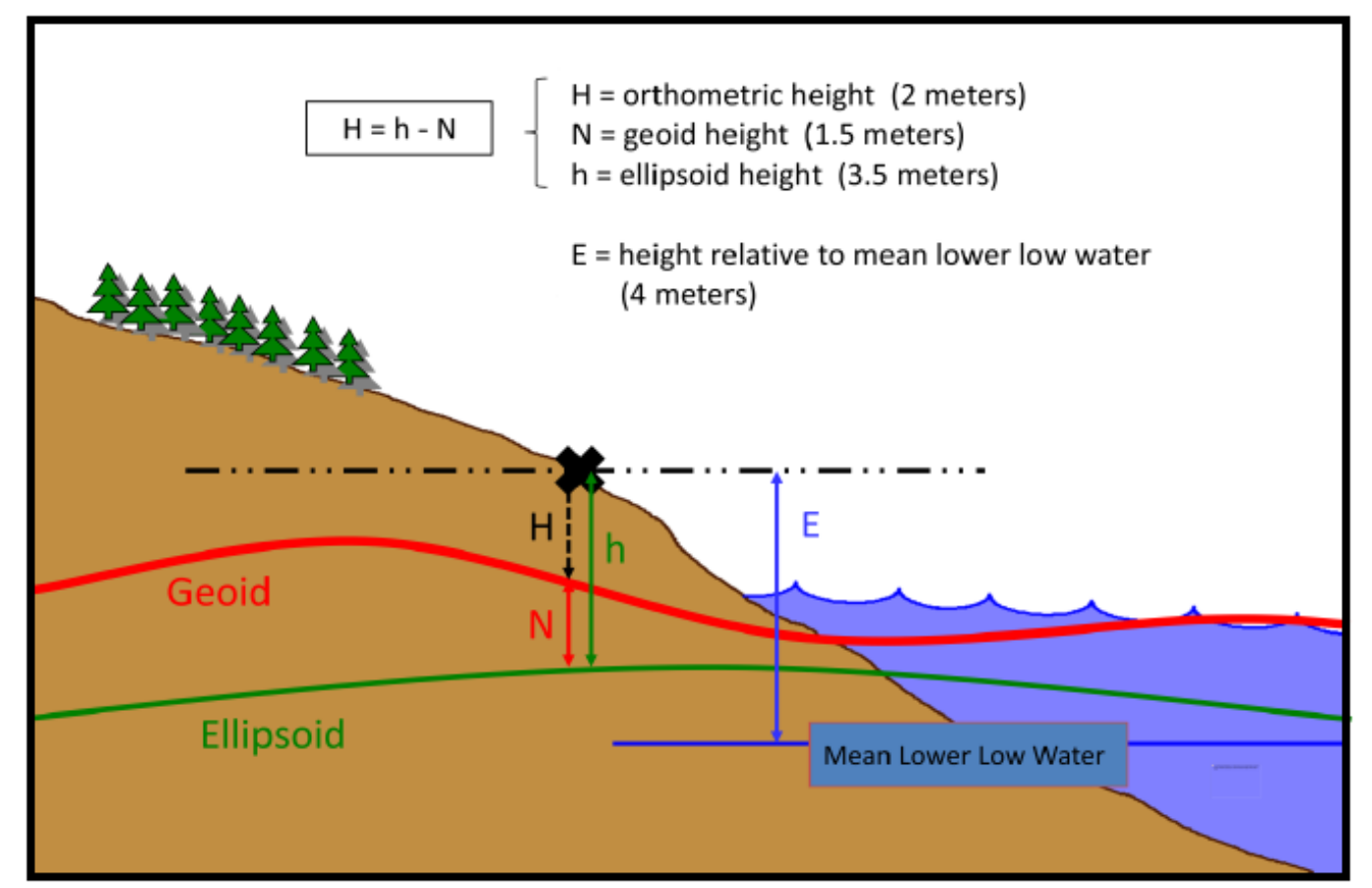

Figure 4. Graphical explanation of how sole-station offset transformations are calculated. Elevations obtained using this method are only valid in the immediate vicinity of the original tide station (Recaptioned illustration from NPS, 2011).

Tidal station and benchmark used to generate datum conversion values

\begin{tabular}{|c|c|c|c|c|c|}
\hline \multirow[b]{2}{*}{$\begin{array}{l}\text { Location } \\
\text { Name }\end{array}$} & \multirow{2}{*}{$\begin{array}{l}\text { Tide } \\
\text { Station } \\
\text { ID }\end{array}$} & \multirow[b]{2}{*}{$\begin{array}{l}\text { Tidal datum } \\
\text { analysis period }\end{array}$} & \multicolumn{2}{|c|}{ Benchmark used for vertical control } & \multirow[b]{2}{*}{$\begin{array}{l}\text { NAVD88 orthometric } \\
\text { height source }\end{array}$} \\
\hline & & & Stamping & $\begin{array}{l}\text { NGS Position ID } \\
\text { (PID) }\end{array}$ & \\
\hline $\begin{array}{l}\text { Shishmaref } \\
\text { Inlet } 2\end{array}$ & 9469854 & $\begin{array}{c}09 / 01 / 2003- \\
09 / 30 / 2003 \\
\end{array}$ & $9469854 \mathrm{~B}$ & BBBH56 & $\begin{array}{l}\text { Shared OPUS solution } \\
9 / 20 / 2003\end{array}$ \\
\hline Kivalina & 9491253 & $\begin{array}{c}09 / 06 / 2003- \\
09 / 27 / 2003\end{array}$ & (unstamped) & BBBH52 & $\begin{array}{l}\text { Shared OPUS solution } \\
10 / 5 / 2003\end{array}$ \\
\hline Unalakleet & 9468333 & $\begin{array}{c}07 / 01 / 2011- \\
08 / 31 / 2011\end{array}$ & 8333 H 2011 & BBCK34 & $\begin{array}{l}\text { Shared OPUS solution } \\
6 / 22 / 2011\end{array}$ \\
\hline Shaktoolik & 9468691 & $\begin{array}{l}07 / 15 / 2010- \\
08 / 23 / 2010\end{array}$ & 8691 A 2010 & BBBZ37 & $\begin{array}{l}\text { Shared OPUS solution } \\
7 / 16 / 2010\end{array}$ \\
\hline (Golovin) & $\mathrm{n} / \mathrm{a}$ & $\begin{array}{l}07 / 07 / 2012- \\
08 / 07 / 2012\end{array}$ & USLM 36511970 & BBDJ67 & $\begin{array}{l}\text { Shared OPUS solution } \\
7 / 27 / 2013\end{array}$ \\
\hline
\end{tabular}




\section{Sources and Accuracies of Component Data - Shishmaref}

\section{Community and Area Maps}

The DCRA basemaps were prepared in 2004 using an orthorectified aerial photo taken June 11, 2004. Property and utility data information was generated by Kawerak Inc. from readily available sources that were current as of December 2004.

\section{Digital Elevation Model}

The best available DEM for this community was derived from a lidar survey conducted in July and August 2004 by the NOAA Coastal Services Center (NOAA, 2004). The native spatial reference system for this dataset is NAD83, with vertical coordinates defined by the GRS80 ellipsoid. The lidar point cloud contains only last returns with vertical point accuracies of $30 \mathrm{~cm}$ RMSE or better.

\section{Confidence Comments}

There is a spurious curvilinear offset in the lidar-derived DEM of less than $1 \mathrm{~m}$ in the vertical that runs approximately parallel to the open ocean coastline of Sarichef Island (see location in fig. 5). Colored elevations in close proximity to these blunders should be used with caution. The DEM coverage is incomplete over Sarichef Island on the DCRA maps; these gaps in coverage are shown as uncolored areas along the shoreline.

Elevation intervals on the map are derived from 2004 source data. Temporal changes, human or naturally induced, could have occurred that would cause the elevations depicted on these map figures to no longer

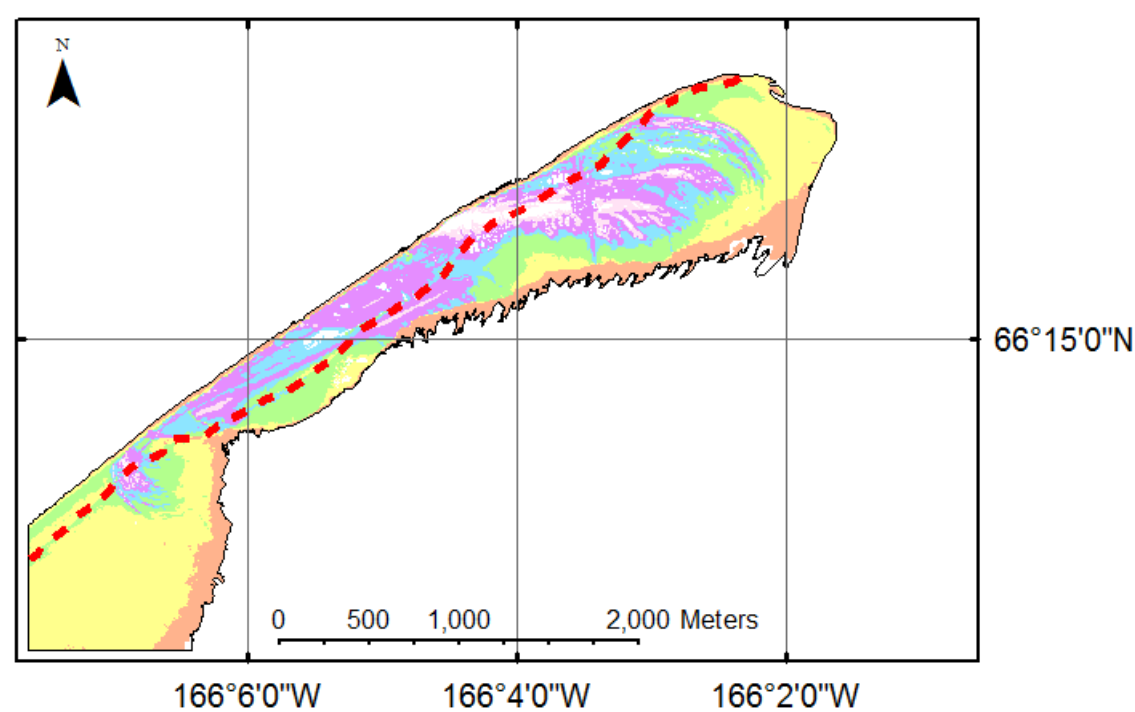

Figure 5. Dashed red line indicates location of a vertical offset error in the lidar data for this area. represent actual surface conditions.

Notable Recent Changes:

- An engineered rock revetment was constructed (from 2008 through 2010) along the open ocean side of Sarichef Island (see fig. 6).

Highlighted Infrastructure:

- Shishmaref High School

- Church evacuation center

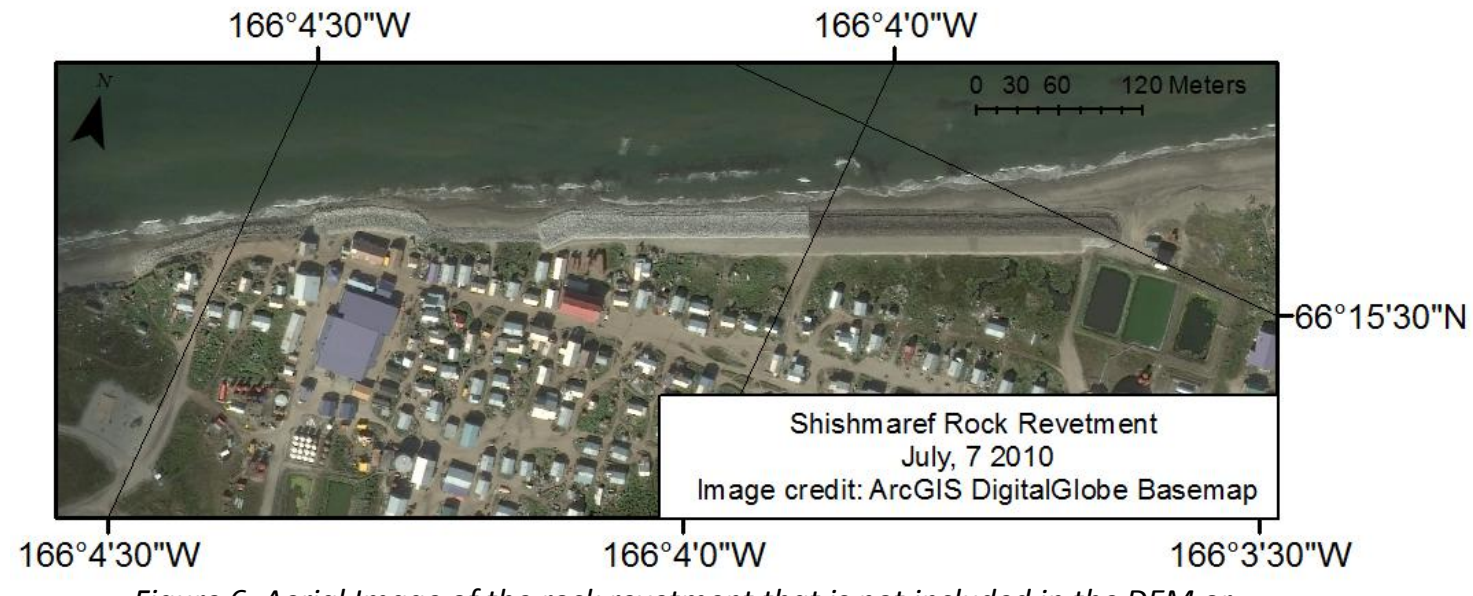

Figure 6. Aerial Image of the rock revetment that is not included in the DEM or basemap imagery. 


\section{Sources and Accuracies of Component Data - Kivalina}

\section{Community and Area Maps}

The DCRA basemaps were prepared in 1999 and an update is currently underway. For this project, the maps have been updated with an orthorectified aerial photo taken in 2013. Property and utility data information was generated from readily available sources that were current as of November 1999.

\section{Digital Elevation Model}

The best available DEM for this community was derived from a lidar survey conducted in July and August 2004 by the NOAA Coastal Services Center (NOAA, 2004). The native spatial reference system for this dataset is NAD83, with vertical coordinates defined by the GRS80 ellipsoid. The lidar point cloud contains only last returns with vertical point accuracies of $30 \mathrm{~cm}$ RMSE or better.

\section{Confidence Comments}

There is a small offset in the lidar-derived DEM of less than $1 \mathrm{~m}$ in the vertical that runs approximately perpendicular to the open ocean coastline of Kivalina on the western edge of the Area Use figure (see location in fig. 7). Colored elevations in close proximity to these blunders should be used with caution. The DEM coverage is incomplete over the land area depicted on the DCRA maps; these gaps in coverage are shown as uncolored areas along the shoreline.

Elevation intervals on the map are derived from 2004 source data. Temporal changes, human or naturally induced, could have occurred that would cause the elevations depicted on these map figures to no longer represent actual surface conditions.

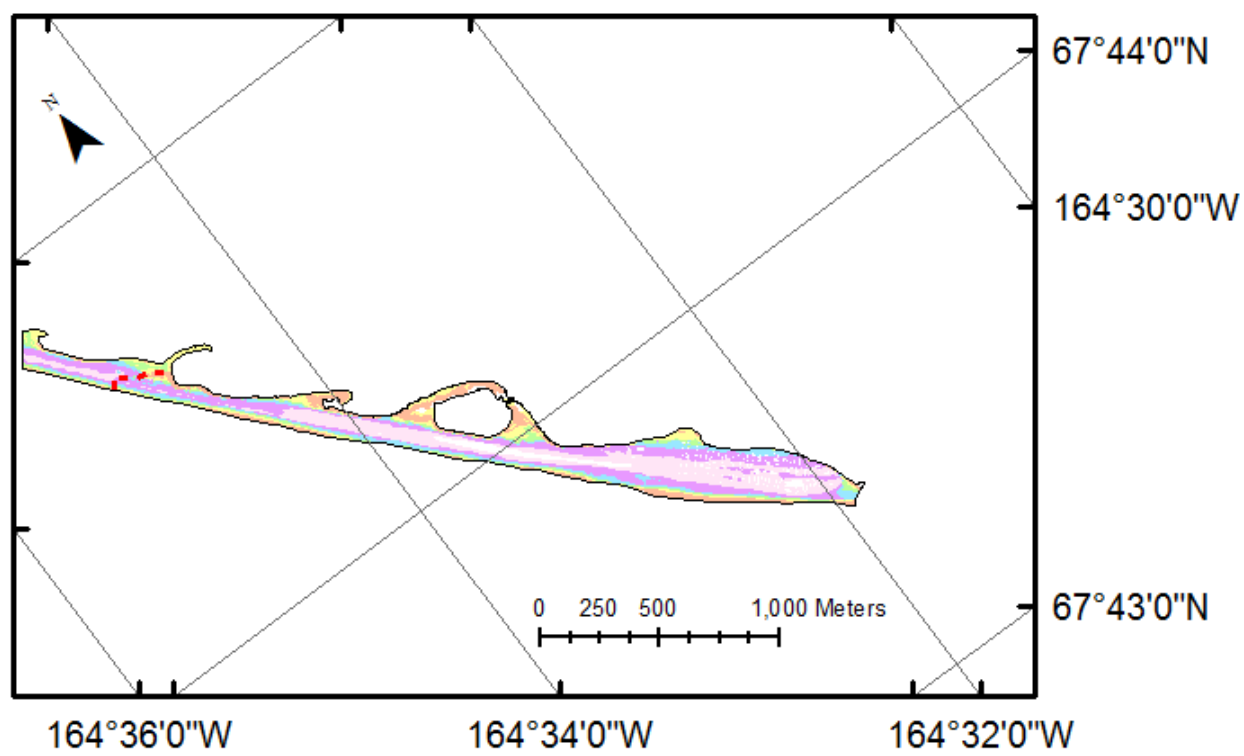

Figure 7. Dashed red line indicates location of a vertical offset error in the lidar data for this area.

Notable Recent Changes:

- An engineered rock revetment was constructed beginning in 2006 on the southeastern end of the island. This structure is visible in the 2013 basemap imagery but is not included in the best available elevation dataset.

- Ongoing coastal processes have reshaped the sand spit at the eastern end of the island.

Highlighted Infrastructure:

- McQueen School

- School tank farm

- AVEC tank farm 


\section{Sources and Accuracies of Component Data - Unalakleet}

\section{Community and Area Maps}

The DCRA basemaps were prepared in 2004 using an orthorectified aerial photo taken June 27, 2004. For this project, the maps have been updated with an orthorectified aerial photo taken September 21, 2014. Property and utility data information was generated by Kawerak Inc. from readily available sources, and was current as of December 2004.

\section{Digital Elevation Model}

The best available DEM for this community was derived from an aerial survey contracted in September 2014 by DGGS. The elevation data was generated by Fairbanks Fodar using a Structure from Motion photogrammetric approach. The native spatial reference system for this dataset is WGS84, with vertical coordinates in NAVD88. The vertical accuracy is estimated to be $25 \mathrm{~cm}$ RMSE or better in areas without dense vegetation.

\section{Confidence Comments}

The photogrammetric technique used to generate this DEM is in an experimental phase at DGGS; it is being tested for a range of applications in the coastal zone. Preliminary assessment of the DEM surface showed good agreement with 2011 DGGS ground control and with known past flood levels. This DEM is a significant improvement over a 2005 lidar-derived surface that predated the construction of an engineered rock revetment (2010; fig. 8) at the Unalakleet River inlet and the raising (+3 feet or 0.9 meters; 2005) of Beach Front Road.

Elevation intervals on the map are derived from 2014 source data. Temporal changes, human or naturally induced, could have occurred that would cause the elevations depicted on these map figures to no longer represent actual surface conditions.

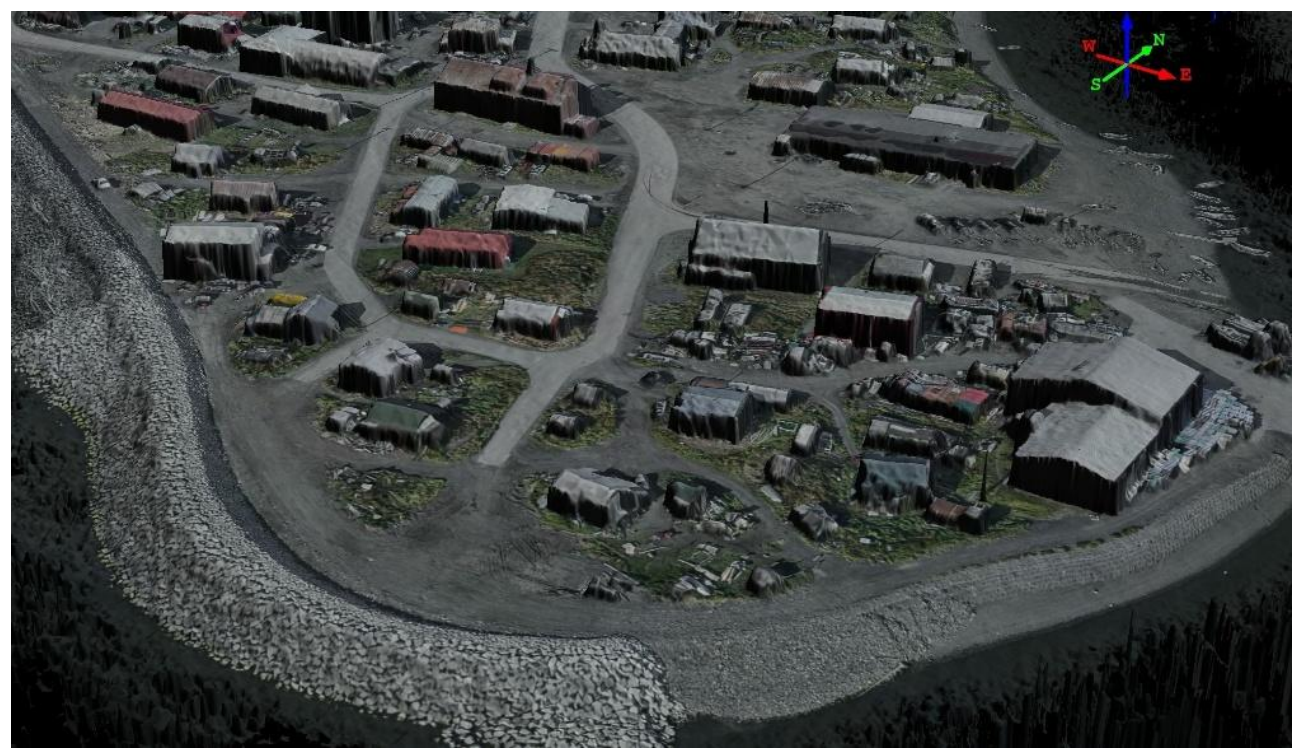

Figure 8. 3-dimensional model view of the Unalakleet revetment looking north from the inlet. (2014 aerial image draped over DEM provided by Fairbanks Fodar, 2014).

Notable Recent Changes:

- None identified in map area at this time.

Highlighted Infrastructure:

- None highlighted at this time. 


\section{Sources and Accuracies of Component Data - Shaktoolik}

\section{Community and Area Maps}

The DCRA basemaps were prepared in 2004 using an orthorectified aerial photo taken June 27, 2004. For this project, the maps have been updated with an orthorectified aerial photo taken September 21, 2014. Property and utility data information was generated by Kawerak Inc. from readily available sources, and was current as of December 2004.

\section{Digital Elevation Model}

The best available DEM for this community was derived from an aerial survey contracted in September 2014 by DGGS. The elevation data were generated by Fairbanks Fodar using a Structure from Motion photogrammetric approach. The native spatial reference system for this dataset is WGS84, with vertical coordinates in NAVD88. The vertical accuracy is estimated to be $25 \mathrm{~cm}$ RMSE or better in areas without dense vegetation.

\section{Confidence Comments}

The photogrammetric technique used to generate this DEM is in an experimental phase at DGGS; it is being tested for a range of applications in the coastal zone. Preliminary assessment of the DEM surface showed good agreement with 2011 DGGS ground control and with known past flood levels. This DEM is a significant improvement over a 2004 photogrammetric DEM associated with the DCRA contour elevations that was very coarse, did not cover critical areas along the evacuation route, and did not reflect recent changes associated with erosion along the coast.

Elevation intervals on the map are derived from 2014 source data. Temporal changes, human or naturally induced, could have occurred that would cause the elevations depicted on these map figures to no longer represent actual

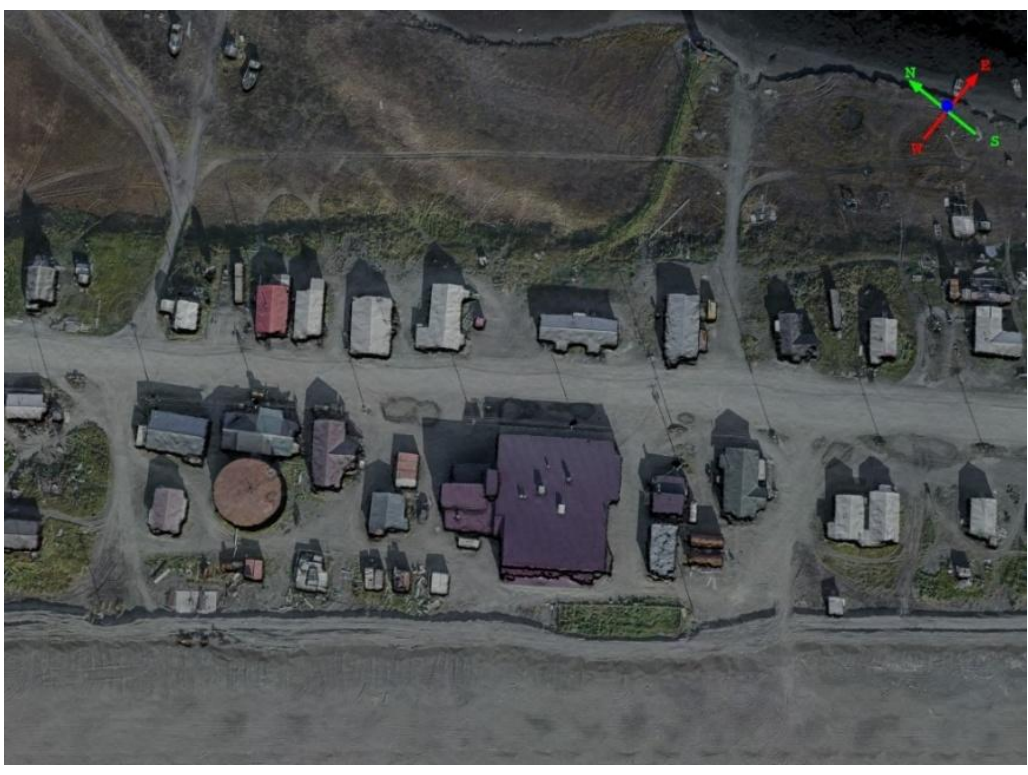

Figure 9. 3-dimensional model view of the berm project under construction in front of the Shaktoolik School (2014 aerial image draped over DEM provided by Fairbanks Fodar, 2014). surface conditions.

Notable Recent Changes:

- The DEM includes a berm along the open-ocean coast that was constructed in 2014 as a locally-led project by Shaktoolik residents (fig. 9).

Highlighted Infrastructure:

- Shaktoolik School

- City fuel tank farm 


\section{Sources and Accuracies of Component Data - Golovin}

\section{Community and Area Maps}

The DCRA basemaps were prepared in 2004 using an orthorectified aerial photo taken June 6, 2004. Property and utility data information was generated by Kawerak Inc. from readily available sources that were current as of December 2004.

\section{Digital Elevation Model}

The best available DEM for this community was derived from a lidar survey that was conducted in November 2013 and was acquired for release by DGGS in September 2014. The native spatial reference system for this dataset is NAD83 (CORS96), with vertical coordinates in NAVD88 (GEOID09). The vertical point accuracies of the last returns are $35 \mathrm{~cm}$ RMSE or better.

\section{Confidence Comments}

The DEM coverage is incomplete over the area shown in the Golovin Area Use Map Sheet 1 . The areas without elevation data are shown as uncolored areas of the map. There is no DEM coverage over the area shown in the Golovin Area Use Map Sheet 2.

There is no published tidal datum for Golovin, Alaska. The presented tidal elevations are an approximation based on water level measurements conducted by DGGS in 2012.

Elevation intervals on the map are derived from 2013 source data. Temporal changes, human or naturally induced, could have occurred that would cause the elevations depicted on these map figures to no longer represent actual surface conditions.

Notable Recent Changes:

- Prior to the 2013 storm season, a local short-term project resulted in the construction of a temporary levee along Antone Street, which is frequently overtopped by flood waters (see fig. 10).

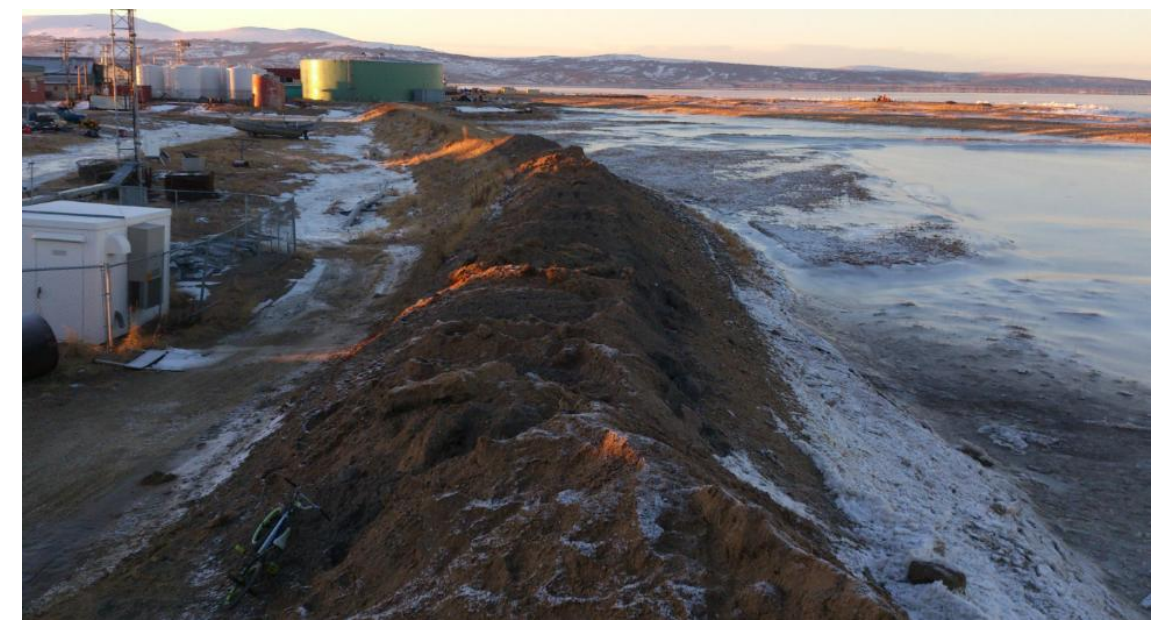

Figure 10. Temporary levee project from fall 2013 (photo by Carol Oliver, 2013).

Highlighted Infrastructure:

- M.L. Olson School

- Power plant

- City fuel tank farm

- Health clinic 


\section{Production Process Steps}

Adapted from the methods presented in the Coastal Inundation Mapping Guidebook and other inundation map recommendations (NOAA, 2009; NOAA 2010).

1. Digital Elevation Model

A. Lidar-derived DEM source lidar processed during acquisition with automated tools available from the NOAA Digital Coast Data Access Viewer

i. Output projection and/or datum transformation: NAD83, UTM (horizontal), NAVD88 (vertical)

ii. Output format: $2 \mathrm{~m}$, 32-bit GeoTiff raster derived from a minimum interpolation of the raw point cloud with small gap filling

B. Elevation data derived from Structure from Motion (SFM) approach (Unalakleet and Shaktoolik) are 18 to $19 \mathrm{~cm}$ raster products (WGS84)

i. Datum transformation: NAD83, UTM (horizontal), NAVD88 (vertical)

C. Raster DEM $\rightarrow$ Elevation-based polygon areas (ArcGIS processing)

i. Reclassified continuous elevation raster into discrete elevation bins. Elevation bin spacing was selected to create evenly spaced colored intervals throughout the entire community, not just areas prone to inundation.

ii. Smoothed edges of binned elevation raster using three iterations of the 'Majority Filter' function in ArcGIS. The input parameters (numbers of neighbors to use and replacement threshold) for the successive runs of the majority filter were eight and half, eight and half, and eight and majority.

iii. Converted binned elevations to polygon layer.

iv. Clipped elevation polygons to shoreline position.

v. Clipped elevation polygons around buildings and infrastructure, and inland water bodies, as appropriate

2. Aerial Photographs $(1: 9,600$ scale; $1: 6,000$ and $1: 14,400$ for Kivalina; $9 \mathrm{~cm}$ resolution for Unalakleet and Shaktoolik)

A. Orthorectified aerial images acquired from DCRA (Alaska State Plane, NAD83)

B. Reprojected to NAD83, UTM

3. DCRA Maps (source ungeoreferenced PDF)

A. The community maps were produced using only a subset of DCRA text and linework to improve legibility. Text or linework not pertaining to buildings, utilities, landmarks, or prominent local features were removed when possible. Text and linework seen in the Area Use Map were not changed.

B. Manually georeferenced DCRA text and linework were transferred to aerial photographs.

Note: The rasters used to generate the elevation polygons in this study are a derived lidar point-cloud product, therefore the vertical accuracy of this surface is not better than the vertical accuracy of the original point returns. Sparse, low vegetation combined with the low-relief terrain is a favorable environment for interpolated lidar DEMs and a 'minimum' interpolation was used to produce low-biased surfaces. A comparison of stable areas in Shishmaref (such as the runway surface) revealed vertical differences of no more than $60 \mathrm{~cm}$ when compared to the interpolated raster $(n=5)$. 


\section{References}

Chapman, R.S., Kim, Sung-Chan, and Mark, D.J., for U.S. Army Corps of Engineers, Alaska District, 2009, Storm damage and flooding evaluation, storm-induced water level prediction study for the western coast of Alaska: Vicksburg, Mississippi, U.S. Army Engineer Research and Development Center, Coastal and Hydraulics Laboratory, $92 \mathrm{p}$.

Division of Community and Regional Affairs (DCRA), 2014, Planning \& Land Management: Community Profile Maps [website], last accessed September 2014: http://commerce.alaska.gov/dnn/dcra/ planninglandmanagement/communityprofilemaps.aspx

Division of Geological \& Geophysical Surveys (DGGS), 2014, Alaska tidal datum portal [website], last accessed August 2014: doi:10.14509/ak-tidal-datum-portal

Division of Homeland Security \& Emergency Management (DHS\&EM), March 2013, Alaska emergency response guide for small communities: Anchorage, Alaska, State of Alaska, Department of Military and Veterans Affairs, 53 p. Note: the Alaska Emergency Response Guide for Small Communities has been recently updated; as of the date of this publication, it is the 2014 version. http://ready.alaska.gov/SEOC/Documents/Alaska\%20 Emergency\%20Response\%20Guide\%20for\%20Small\%20Communities\%202014\%20Final.pdf

Federal Emergency Management Agency (FEMA), 2009, Digital flood insurance rate map database, City of Shishmaref, AK, USA [electronic resource]: Washington, DC, U.S. Federal Emergency Management Agency.

Kinsman, N.E.M., and DeRaps, M.R., 2012, Coastal hazard field investigations in response to the November 2011 Bering Sea storm, Norton Sound, Alaska: Alaska Division of Geological \& Geophysical Surveys Report of Investigation 2012-2 v. 1.1, 51 p., 1 sheet. doi:10.14509/24484

National Oceanic and Atmospheric Administration (NOAA), 2014, Tides \& Currents, Center for Operational Oceanographic Products and Services (CO-OPS) [website], last accessed June 2014: http://tidesandcurrents .noaa.gov/

NOAA, 2010, Technical considerations for use of geospatial data in sea level change mapping and assessment: Silver Spring, MD, National Ocean Service, $130 \mathrm{p}$.

NOAA, 2009, Coastal inundation mapping guidebook: Charleston, SC, Coastal Services Center, 26 p.

National Oceanic and Atmospheric Administration (NOAA), Department of Commerce (DOC), National Ocean Service (NOS), and Coastal Services Center (CSC), 2004, 2004 Alaska lidar mapping: Charleston, SC, NOAA Ocean Service, Coastal Services Center, digital data available online at http://www.csc.noaa.gov/lidar

National Park Service (NPS), 2011, Accurate elevations in coastal national parks-Preparing and planning for impacts of climate change: Resource Information Services Division, $50 \mathrm{p}$.

Natural Resources Conservation Service (NCRS), 2003, Flood plain management study for the City \& Native Village of Unalakleet, Alaska: United States Department of Agriculture, $79 \mathrm{p}$.

Smith, Jacquelyn R., 2014, Patterns and potential solutions to coastal geohazards at Golovin, Alaska: Fairbanks, Alaska, University of Alaska Fairbanks, M.S. thesis, 109 p.

Southerland, L.E., and Kinsman, N.E.M., 2014, Lidar data for Unalakleet, Alaska, collected in October 27, 2005: Alaska Division of Geological \& Geophysical Surveys Raw Data File 2014-2, 12 p. doi:10.14509/27121

United States Army Corps of Engineers (USACE), 2011a, Shaktoolik coastal flooding analysis: Alaska District, 73 p.

United States Army Corps of Engineers (USACE), 2011b, Flood hazard data for Alaska communities: Alaska District, Civil Works Floodplain Management, available online. http://www.poa.usace.army.mil/en/cw/fld haz/floodplain index.htm

Wise, James L., Comiskey, Albert L., and Becker, Richard, 1981, Storm surge climatology and forecasting in Alaska: Anchorage, Alaska, Arctic Environmental Information and Data Center, University of Alaska, 32 p. 